\title{
DISTRIBUTION AND ORIGIN OF ORGANIC MATTER IN THE BALTIC SEA SEDIMENTS DATED WITH ${ }^{210} \mathrm{~Pb}$ AND ${ }^{137} \mathrm{Cs}$
}

\author{
ALEKSANDRA SZCZEPAŃSKA ${ }^{1}$, AGATA ZABORSKA ${ }^{1}$, ANNA MACIEJEWSKA ${ }^{1}$, \\ KAROL KULIŃSKI ${ }^{1}$ and JANUSZ PEMPKOWIAK ${ }^{1,2}$ \\ ${ }^{1}$ Institute of Oceanology Polish Academy of Sciences, Powstańców Warszawy 55, 81-712 Sopot, Poland \\ ${ }^{2}$ Koszalin University of Technology, Faculty of Construction and Environmental Engineering, \\ Śniadeckich 2, 75-453 Koszalin, Poland
}

Received 1 May 2011

Accepted 2 November 2011

\begin{abstract}
Organic carbon deposited in marine sediments is an important part of the global carbon cycle. The knowledge concerning the role of shelf seas (including the Baltic Sea) in the carbon cycle has increased substantially, however organic carbon accumulation rates in the Baltic sediments still require clarification.

This paper describes methods used for assessing organic carbon and nitrogen accumulation rates in six sediment cores collected in the sediment accumulation areas in the Baltic Sea. Mass sediment accumulation rates were based on ${ }^{210} \mathrm{~Pb}$ method validated by ${ }^{137} \mathrm{Cs}$ measurements. The organic carbon accumulation rates ranged from 18 to $75 \mathrm{~g} \cdot \mathrm{C} \cdot \mathrm{m}^{-2} \cdot \mathrm{yr}^{-1}$. The $\mathrm{C} / \mathrm{N}$ ratios and $\delta^{13} \mathrm{C}$ were used to access sedimentary organic matter provenance. The $\mathrm{C} / \mathrm{N}$ ratios in the investigated cores vary in the range from 7.4 to 9.6 , while $\delta^{13} \mathrm{C}$ ranged from $-24.4 \%$ o to $-26.4 \%$. Results of the terrestrial organic matter contribution in the sedimentary organic matter were calculated basing on $\delta^{13} \mathrm{C}$ using the end member approach. Large proportion (41-73\%) of the sedimentary organic carbon originates on land.

The obtained results indicate the Baltic Sea sediments as an important sink for organic carbon. Substantial fraction of the sedimentary load originates on land.
\end{abstract}

Keywords: accumulation rates, marine sediments, organic carbon, nitrogen, stable carbon isotopes.

\section{INTRODUCTION}

The carbon cycle is one of the major biogeochemical cycles as regards the flow of matter and energy in the environment. The main constituent of the carbon cycle is carbon dioxide $\left(\mathrm{CO}_{2}\right)$. In recent decades a significant increase of carbon dioxide in the atmosphere due to fossil fuel burning has been observed, resulting in global warming (Chen and Borges, 2009; HELCOM, 2007; IPCC, 2007).

Corresponding author: A. Szczepańska e-mail: olcia@iopan.gda.pl
It is believed that almost $35 \%$ of anthropogenic $\mathrm{CO}_{2}$ emission is absorbed by seas and oceans (Takahashi et al., 2009). Almost $1 / 3$ of this load is absorbed by shelf seas. During the last decade, knowledge about the role of shelf seas, in the carbon cycle has increased considerably. It has been estimated that the shelf seas are responsible for approximately $20 \%$ of marine organic matter production and about $80 \%$ of the total organic matter load deposited to marine sediments (Borges, 2005). The Baltic Sea plays a significant role among the shelf seas in this context (Thomas et al., 2010).

The Baltic Sea is described as an autotrophic semienclosed brackish sea (Thomas et al., 2003). Considera- 
ble amounts of nutrients, mostly from agriculture and industry, enter the sea from rivers, making the Baltic Sea one of the most productive marine ecosystems (Emelyanow, 1995; Gudelis and Jemielianowa, 1982; HELCOM 2006; Thomas et al., 2003). The most important sources of organic matter in the Baltic Sea are: primary production, river runoff and import from the North Sea (Wasmund and Uhlig, 2003; Kuliński and Pempkowiak, 2011). However, it must be remembered that the Baltic Sea is a net source of organic matter for the North Sea (Kuliński at al., 2011; Kuliński and Pempkowiak, 2012). A large part of the Baltic Sea catchment area includes agricultural areas that export large amounts of nutrients (Emelyanow, 1995; Gudelis and Jemielianowa, 1982). The increase of nutrients enhances the „biological pump” that causes $\mathrm{CO}_{2}$ absorption and assimilation to organic matter by phytoplankton. A large part of organic matter both produced in the sea and brought to the sea is incorporated in the sediments (Kuliński and Pempkowiak, 2008). Existing data are insufficient to quantify the load of organic carbon that is accumulated in sediments. Preliminary estimates indicate that the amount of organic carbon deposited into the sediments is about $3.9 \mathrm{Tg} \mathrm{\textrm {C } _ { \text { org } }}$ $\mathrm{yr}^{-1}\left(\mathrm{Tg}=10^{12} \mathrm{~g}\right)$ (Pempkowiak, 1985). However, the exact value is unknown (HELCOM, 2004; Kuliński and Pempkowiak, 2012). Estimates are uncertain due to limited amount of data on both sediment accumulation rates and the range of organic carbon concentrations in bottom sediments.

Nitrogen is an important biogenic element that is believed to be a limiting factor for organic matter primary production in the Baltic Sea (Dzierzbicka-Głowacka et al., 2011; Hongisto, 2011). Although, sources of nitrogen to the Baltic are well established, deposition to sediments still requires further quantification (Lysiak-Pastuszak, 2000; Thomas et al., 2003).

Using mass sediment accumulation rates, derived from ${ }^{210} \mathrm{~Pb}$ and ${ }^{137} \mathrm{Cs}$ profiles, and concentrations in sediments of organic carbon and total nitrogen, accumulation rates of both these elements in the sediments of the Baltic Sea were calculated. The study was carried out on sediment cores collected from depositional areas of the sea. The results are essential for carbon and nitrogen budget calculations in the Baltic Sea.

\section{EXPERIMENTAL}

\section{Study area}

The Baltic Sea is the second largest brackish water body in the world. It extends between the $10-30^{\circ} \mathrm{E}$ and $54-64^{\circ} \mathrm{N}$. The surface area of the Sea is equal to 415000 $\mathrm{km}^{2}$ (including Kattegat) (HELCOM 2007; Lass and Matthäus, 2008). The brackish nature of the Baltic Sea is due to the combination of the high river water discharge and the limited inflows of saline water from the North Sea. The inflows of saline water lead to a stable stratification of water in the Baltic basins where water depth ex- ceeds about $80 \mathrm{~m}$. Water budget of the sea is further influenced by precipitation that exceeds evaporation. Halocline resulting in limited mixing of water masses, and the progressive eutrophication, are the cause of oxygen deficits due to mineralization of organic matter. Direct discharges of treated sewage are of importance due to the load of nutrients they carry. Increasing eutrophication also implies phytoplankton blooms, enhancing the „biological pump" phenomenon (Dzierzbicka-Głowacka et al., 2010).

The Gotland Deep (250 m depth) is a flat bottom basin with both gentle and steep slopes and with predominantly soft bottom (silty and muddy sediments) in the Eastern Gotland Basin, and both soft and hard bottom, equally distributed, in the Western Gotland Basin. The stratification of the water column causes a decrease of oxygen concentration with depth and promotes bottom water oxygen depletion. In the Eastern Gotland Basin, halocline and pycnocline are located at the depth of 60-70 m, while in the Western Gotland Basin - at the depth of 50-60 m (Hagen and Feistel, 2004; Walter et al., 2006; Voipio, 1981).

The Gdańsk Deep is a circular, flat bottom basin covered by silty and muddy sediments. Inflows of saline water lead to the formation of halocline at the depth of 60-70 $\mathrm{m}$ and cause a deficiency of oxygen, accompanied by an occurrence of hydrogen sulfide. The surface water layers are characterized by low salinity of $7.1 \mathrm{psu}$ and by seasonal fluctuations of temperature. The subsurface layers are characterized by stable temperature and salinity in the range of 9-11 psu (Ebbing et al., 2002; Emelyanow, 2002; Leipe et al., 2011; Szczepańska and Uścinowicz, 1994).

\section{Materials and methods}

Sediment cores were collected using Niemisto and GEMAX corers (equipped with two $50 \mathrm{~cm}$ long, $10 \mathrm{~cm}$ diameter core tubes) during the Oceania cruises, at 6 selected stations in the southern part of the Baltic Sea, in 2007 (Table 1, Fig. 1). Five sediment cores were collected from the areas characterized by steady sedimentation (Gotland Basin and Gdańsk Basin), while one sediment core was collected between the Oland Island and the Swedish coast, where the water dynamics have a strong impact on sedimentation processes. Profiles of salinity and temperature against depth measured using a CTD profiler proved water stratification at the study sites. All sediment cores were muddy, and characterized by an intensive smell of hydrogen sulfide. The sediment cores were brownish at the surface layers changing to grey and dark grey in the deeper sediment layers. Water from above the sediment surface was analyzed for basic parameters like salinity, $\mathrm{O}_{2}$ and redox potentials. Immediately after collecting cores were sliced into $10 \mathrm{~mm}$ thick layers and frozen at $-20^{\circ} \mathrm{C}$. After thawing in laboratory sediment samples were freeze-dried at $60^{\circ} \mathrm{C}$ and homogenized. Before analysis sediments samples were passed 
through $0.063 \mathrm{~mm}$ mesh sieve, the $<0.063 \mathrm{~mm}$ fraction was further analyzed. The following analyses were carried out: moisture (bulk sediments), loss of ignition, $\mathrm{C}_{\mathrm{org}}$, $\mathrm{N}_{\text {tot }}$, activity concentrations of ${ }^{210} \mathrm{~Pb}$ and ${ }^{137} \mathrm{Cs}$, carbon stable isotopes.

The moisture was calculated using the formula:

$M=\frac{m_{w}-m_{d}}{m_{w}} \cdot 100 \%$

where: $M$ is moisture (\%), $m_{w}$ is wet sample mass in grams $(\mathrm{g}), m_{d}$ is dry sample mass $(\mathrm{g})$.

Sediment porosity was calculated according to the formula:

$P=\frac{w_{m}}{d_{w} \cdot V}$

where: $P$ is sediment porosity, $w_{m}$ is water weight in the sample (wet sample weight - dry sample weight), $d_{w}$ is water density $\left(1.00 \mathrm{~g} \mathrm{~cm}^{-3}\right)$ and $V$ is vial volume.

Loss of ignition (LOI) was determined by burning dry samples in a muffle oven at $450^{\circ} \mathrm{C}$ for 8 hours.

Organic carbon and total nitrogen concentrations, and stable carbon isotopes composition $\left(\delta^{13} \mathrm{C}\right)$ were measured in an Elemental Analyzer Flash EA 1112 Series com-

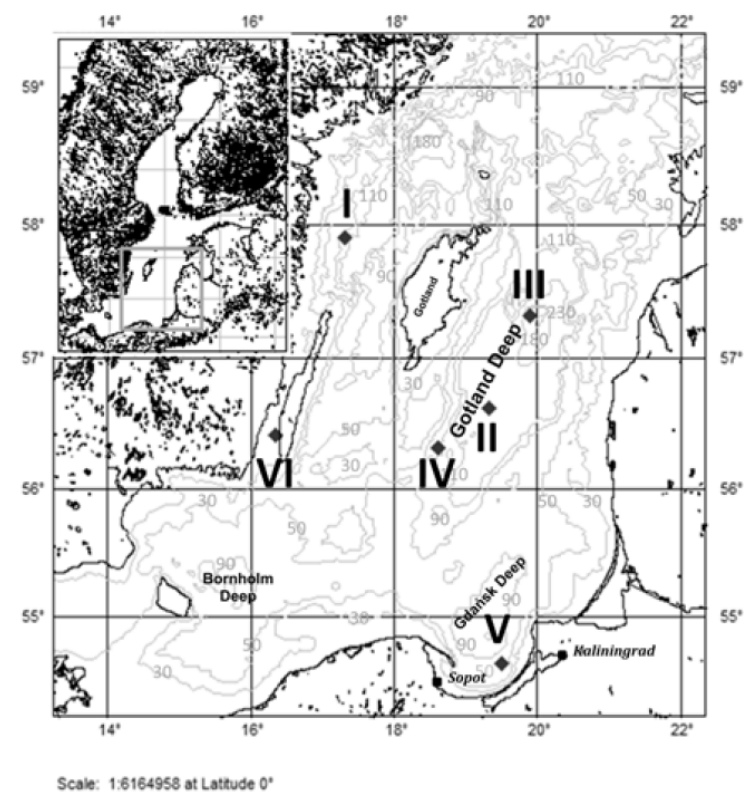

Fig. 1. Location of the sampling station. bined with the Isotopic Ratio Mass Spectrometer IRMS Delta V Advantage (Thermo Electron Corp., Germany). The reference gas was pure $\mathrm{N}_{2}$ and $\mathrm{CO}_{2}$ gas calibrated against IAEA standards: CO-8 and USGS40 for $\delta^{13} \mathrm{C}$ and $\mathrm{N}-1$ and USGS40 for $\delta^{15} \mathrm{~N}$. The standard deviation was less than $0.15 \%$ and $0.20 \%$ for $\delta^{13} \mathrm{C}$ and $\delta^{15} \mathrm{~N}$ respectively. Quality control of $\mathrm{C}$ and $\mathrm{N}$ concentrations measurements was carried out with standard materials supplied by the Thermo Electron Corp. The used methodology proved satisfactory accuracy and precision (average recovery 99.1\% for $\mathrm{C}$ and $98.5 \%$ for $\mathrm{N}$ ). Before analysis, carbonates were removed from the samples by acidification ( $\left.\mathrm{HCl}_{\text {conc }}\right)$ for 24 hours.

Determination of ${ }^{210} \mathrm{~Pb}$ activity concentration was performed assuming secular equilibrium between ${ }^{210} \mathrm{~Pb}$ and ${ }^{210} \mathrm{Po}$, according to the method developed by Flynn (1968) and adopted by Pempkowiak (1991). $100 \mathrm{mg}$ of dry sediment was spiked with known activity of ${ }^{209} \mathrm{Po}$, subsequently the sample was digested with $2 \mathrm{~cm}^{3}$ of perchloric acid followed by $4 \mathrm{~cm}^{3}$ of fluoric acid. The so obtained solution was transferred, with $6 \mathrm{M} \mathrm{HCl}$, to a Teflon vessel and evaporated to dryness. The dry residue was dissolved in $0.5 \mathrm{~mol} \cdot \mathrm{dm}^{-3}$ hydrochloric acid and ${ }^{209} \mathrm{Po}$ and ${ }^{210} \mathrm{Po}$ were spontaneously deposited onto silver disks of $15 \mathrm{~mm}$ diameter $\left(90^{\circ} \mathrm{C}, 4\right.$ hours, continuous stirring). The disks were counted for 20 hours in an alpha spectrometer, type 720002, equipped with a silicon detector (Canberra). Counting error $(1 \sigma)$ was lower than $10 \%$.

The ${ }^{137} \mathrm{Cs}$ was introduced into the environment as a consequence of nuclear weapons tests in the period from 1950-1976 (Abril, 2003). The significant quantities of ${ }^{137} \mathrm{Cs}$ were introduced also as a result of the Chernobyl accident in 1986 (Kankaanpaa et al., 1997; Lima et al., 2004; Suplińska, 2002; Suplińska, 2008). The ${ }^{137}$ Cs specific activity was determined in a gamma spectrometer equipped with a Canberra high-purity Ge detector. The analyses were carried out on $20 \mathrm{~g}$ samples packed in vials of a cylindrical standard geometry $(65 \mathrm{~mm} \times \varphi 20 \mathrm{~mm})$. Calibration of the counter was performed based on the reference materials obtained from IAEA (IAEA-300 and IAEA-315). The counting time was at least $24 \mathrm{~h}$. Counting error $(1 \sigma)$ was lower than $10 \%$. No correction for ${ }^{137} \mathrm{Cs}$ decay was applied as the useful information used was just the presence of the radionuclide at a given depth.

Sediment accumulation rates (SAR in $\mathrm{cm} \cdot \mathrm{yr}^{-1}$ ) were determined from profiles of excess ${ }^{210} \mathrm{~Pb}$ activity concentrations versus porosity-corrected depth in sediments.

Table 1. Location of cores sampling sites and sediment bulk properties.

\begin{tabular}{cccccc}
\hline Station & Latitude $^{\circ} \mathbf{N}$ & Longitude $^{\circ} \mathrm{E}$ & Depth $(\mathbf{m})$ & Core length (cm) & Porosity \\
\hline I & $57^{\circ} 54$ & $17^{\circ} 18$ & 80 & 25 & $0.76-0.89$ \\
II & $56^{\circ} 37$ & $19^{\circ} 20$ & 135 & 28 & $0.81-0.98$ \\
III & $57^{\circ} 19$ & $19^{\circ} 54$ & 230 & 23 & $0.76-0.97$ \\
IV & $56^{\circ} 19$ & $18^{\circ} 36$ & 85 & 23 & $0.70-0.93$ \\
V & $54^{\circ} 37$ & $19^{\circ} 30$ & 55 & 42 & $0.81-0.95$ \\
VI & $56^{\circ} 03$ & $16^{\circ} 02$ & 47 & 35 & $0.86-0.94$ \\
\hline
\end{tabular}


The supported ${ }^{210} \mathrm{~Pb}_{\text {supp }}$ activity concentration was calculated as the mean of activities in layers, below the decay zone, with constant radiolead activity. In the case of surface mixing, sediment accumulation rates were calculated from the part of profiles below mixed zone.

${ }^{210} \mathrm{~Pb}_{\text {ex }}$ activity concentration was calculated as the difference between total ${ }^{210} \mathrm{~Pb}_{\text {tot }}$ and ${ }^{210} \mathrm{~Pb}_{\text {supp }}$ activities:

${ }^{210} \mathrm{~Pb}_{\text {ex }}={ }^{210} \mathrm{~Pb}_{\text {tot }}-{ }^{210} \mathrm{~Pb}_{\text {supp }}$

Sediment accumulation rates were calculated according to the formula:

$\mathrm{A}_{\mathrm{t}}=\mathrm{A}_{0} \mathrm{e}^{-\lambda \mathrm{t}}$

where $A_{t}$ is the ${ }^{210} \mathrm{~Pb}$ activity at time $t, A_{0}$ is the activity at time $0, \lambda$ is the radionuclide decay constant (for $\lambda=0.0311 / \mathrm{y}$ ).

When $t$ is replaced by $t=x^{x} / v(x-$ depth of a given sediment layer, $v$ - sedimentation rate) the above formula can be rewritten:

$\ln \mathrm{A}^{210} \mathrm{~Pb}_{\mathrm{ex}}(\mathrm{x})=\ln \mathrm{A}^{210} \mathrm{~Pb}_{\mathrm{ex}}(0)-(\lambda / v) \mathrm{x}$

where: $A^{210} P b_{e x}(x)$ is the activity at layer $x, A^{210} P b_{e x}(0)$ is the activity at surface (layer 0 ), $\lambda$ is the decay constant, $v$ is the sediment accumulation rate.

The constant rate of supply (CRS) model was used throughout the calculations (Robins, 1978; Zaborska et al., 2007).

$A_{x}=A_{0} e^{-\lambda t}$

$x / v=1 / \lambda \ln \Sigma\left(A_{c x}\right) / \ln \Sigma\left(A_{c 0}\right)$

where $\Sigma A_{c x}$ is the cumulative residual ${ }^{210} \mathrm{~Pb}_{\text {ex }}$ activity beneath sediments of depth $\mathrm{x}, \Sigma A_{c 0}$ is the total ${ }^{210} \mathrm{~Pb}_{\mathrm{ex}}$ activity in the sediment column, $x$ is the cumulative depth $(\mathrm{cm}), v$ is the sediment accumulation rate $\left(\mathrm{cm} \cdot \mathrm{yr}^{-1}\right), t$ is the age of the sediment (years).

Sediment mass accumulation rates (MAR in $\left.\mathrm{g} \cdot \mathrm{m}^{-2} \cdot \mathrm{yr}^{-1}\right)$ were calculated using the ${ }^{210} \mathrm{~Pb}_{\mathrm{ex}}$ after transforming sediment depth to mass depth (Robins, 1978; Zaborska et al., 2008). Cumulative dry mass depth was estimated according to the formula:

$D_{D}=h \cdot D_{s} \cdot(1-P)$

$\Sigma D_{D}=\Sigma\left(h_{i+1}-h_{1}\right) \cdot\left(1-P_{i}\right) \cdot D_{i}$

where $D_{D}$ is the dry mass depth, $h$ is the layer thickness, $D_{S}$ is the dry sediment density and $P$ is the layer porosity.

To validate the so obtained sediment accumulation rates, profiles of the man-made radionuclide ${ }^{137} \mathrm{Cs}$ were used. Actual (measured), and expected (basing on ${ }^{210} \mathrm{~Pb}$ datings) depths of ${ }^{137} \mathrm{Cs}$ occurrence were compared. If both depths agreed (3 cores), sediment age determinations were accepted. If both depths were different ( 3 cores) then the mixing depth of surface sediments was adjusted to give an agreement between the expected and the actual ${ }^{137} \mathrm{Cs}$ occurrence depths.

Organic carbon and total nitrogen accumulation rates were calculated as the product of mass sediment accumulation rates $\left(\mathrm{g} \cdot \mathrm{m}^{-2} \cdot \mathrm{yr}^{-1}\right)$ and organic carbon concentrations and total nitrogen concentrations respectively. Only the surface, above the mixed depth, organic carbon concentrations was used, to get the flux of a newly deposited organic carbon.

\section{RESULTS AND DISCUSSION}

\section{Sediment accumulation rates}

The highest total ${ }^{210} \mathrm{~Pb}\left({ }^{210} \mathrm{~Pb}\right.$ tot $)$ activity concentrations were measured in sediment samples from station VI, where they range from $906 \pm 15 \mathrm{~Bq} / \mathrm{kg}$ at the sediment surface to $211 \pm 11 \mathrm{~Bq} / \mathrm{kg}$ at the lower sediment section. The lowest total ${ }^{210} \mathrm{~Pb}$ activity concentrations are measured in sediments collected at station I. They range from $172 \pm 10 \mathrm{~Bq} / \mathrm{kg}$ to $26 \pm 1.2 \mathrm{~Bq} / \mathrm{kg}$ (Fig. 2a.). The high value of ${ }^{210} \mathrm{~Pb}$ activity concentration in sediments from station VI could be due to the Emar river that enters the Kalmar Sund nearby the location of the sampling station.

Linear accumulation rates of sediments in the investigated cores vary in the range from $0.06 \mathrm{~cm} \cdot \mathrm{yr}^{-1}$ at station IV to $0.16 \mathrm{~cm} \cdot \mathrm{yr}^{-1}$ at station VI. Surface layers of cores from stations I, II, III and VI were mixed, which may be caused by bioturbation or by physical processes, e.g. wave induced water movement - strong enough to affect deposited sediments (e.g. station VI). In the course of mixing, sediments may be resuspended and the fine grained fraction may be washed out.

Mass sediment accumulation rates, below the depth of surface sediment mixing, vary from 159 to $534 \mathrm{~g} \mathrm{~m}^{-2} \cdot \mathrm{yr}^{-1}$. The highest mass sediment accumulation rate was found at station I (534 $\left.\mathrm{g} \cdot \mathrm{m}^{-2} \cdot \mathrm{yr}^{-1}\right)$ and at station III $\left(461 \mathrm{~g} \cdot \mathrm{m}^{-2} \cdot \mathrm{yr}^{-1}\right)$. While the mass sediment accumulation rate at station II reached a value of just $160 \mathrm{~g} \cdot \mathrm{m}^{-2} \cdot \mathrm{yr}^{-1}$ (Table 2).

The results are well in the ranges reported earlier for the Baltic sediments (Hille et al., 2006; Pempkowiak, 1991; Szczepańska et al., 2009; Suplińska, 2008; Widrowski and Pempkowiak, 1986).

The activity concentrations of ${ }^{137} \mathrm{Cs}$ in sediments differ depending on sampling site and sampling depth (Fig. 2b.). The highest concentration is observed at the station $\mathrm{V}$, localized in the Gdansk Deep, amounting to about $430 \pm 18 \mathrm{~Bq} / \mathrm{kg}$ in the surface layer, while the lowest - at station IV where the activity concentration is about $80 \pm 6 \mathrm{~Bq} / \mathrm{kg}$ at surface sediments. Ranges of radiocesium activity concentrations in the surface sediments reported earlier (Pempkowiak, 1991; Suplińska, 2002) agree well with our results.

\section{Accumulation rates of organic carbon}

Organic carbon concentrations measured in the all six investigated sediment cores are presented in Fig. 3a. The 
highest organic carbon concentration $\left(\mathrm{C}_{\mathrm{org}}\right)$, ranging from $10.13 \%$ at the surface to $4.56 \%$ in deeper layers was measured in sediments from station II, situated on the
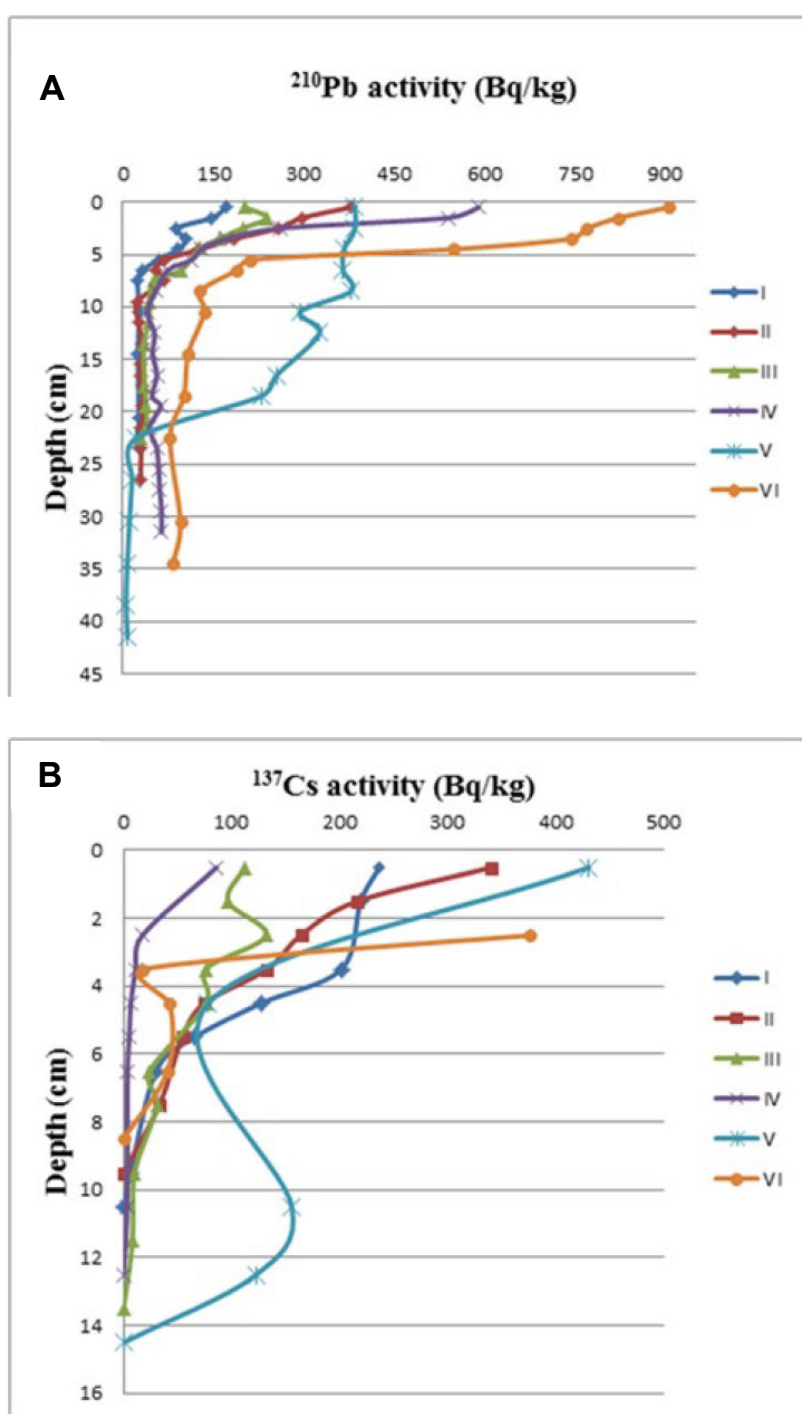

Fig. 2. $A-{ }^{210} \mathrm{~Pb}$ activity concentrations against sediment depth in the core, $B-{ }^{137} C s$ activity concentrations against sediment depth in the core. southern side of the Gotland Deep. At station IV $\mathrm{C}_{\text {org }}$ concentration reached value of only $5.47 \%$ at the surface layer and decreased to about $3.73 \%$ in deeper layers.

Organic carbon accumulation rates $\left(\mathrm{g} \cdot \mathrm{C} \cdot \mathrm{m}^{-2} \cdot \mathrm{yr}^{-1}\right)$ calculated as a product of the mass sediment accumulation rates and the organic carbon concentrations vary in the range from $18 \mathrm{~g} \cdot \mathrm{C} \cdot \mathrm{m}^{-2} \cdot \mathrm{yr}^{-1}$ at station IV to $75 \mathrm{~g} \cdot \mathrm{C} \cdot \mathrm{m}^{-2} \cdot \mathrm{yr}^{-1}$ at station VI (Table 2).

The average organic carbon accumulation rate observed at stations II and III (Gotland Deep) is about $33 \mathrm{~g} \cdot \mathrm{C} \cdot \mathrm{m}^{-2} \cdot \mathrm{yr}^{-1}$. The value is within ranges obtained by Emeis et al. (2000) (about $27 \mathrm{~g} \cdot \mathrm{m}^{-2} \cdot \mathrm{yr}^{-1}$ ) and Struck et al. (2000) (about $30 \mathrm{~g} \cdot \mathrm{m}^{-2} \cdot \mathrm{yr}^{-1}$ ) for the southern Baltic.

The organic carbon accumulation rate result calculated for the station $\mathrm{V}$ amounts to $27 \mathrm{~g} \cdot \mathrm{C} \cdot \mathrm{m}^{-2} \cdot \mathrm{yr}^{-1}$. The value is smaller than the literature values for the Gdańsk Deep (Emeis et al., 2000, about $60 \mathrm{~g} \cdot \mathrm{m}^{-2} \cdot \mathrm{yr}^{-1}$ ), although the mass sediment accumulation rate value is similar to the literature values for this region (MAR at station $\mathrm{V}-410 \mathrm{~g} \cdot \mathrm{m}^{-2} \cdot \mathrm{yr}^{-1}$, MAR obtained by Pempkowiak, 1991 - about $\left.510 \mathrm{~g} \cdot \mathrm{m}^{-2} \cdot \mathrm{yr}^{-1}\right)$. The difference is caused by low levels of organic carbon concentrations, measured in sediment samples from core number $\mathrm{V}$, amounting to about $6.48 \%$ at the surface and just $2.87 \%$ in deeper segments of the sediment core. The low concentrations, most likely, are caused by location of the sampling site at the margin of the Gdańsk Deep.

Profiles of organic carbon concentrations in recent bottom sediments of the Baltic Sea indicate that organic matter concentrations decrease with sediments depth. This is attributed to the recent increased organic matter deposition caused by eutrophication (Emeis et al., 2000; Voss et al., 2000). Another important factor contributing to this phenomenon is mineralization of labile part of organic matter (Kuliński and Pempkowiak, 2012). Such a trend is observed generally at station II, III, IV and V. At station III the typical decrease is followed by an increase in the subsurface sediment layers. This increase may suggest that 100-150 years ago, at this particular location, there occurred much higher deposition of organic matter that has been buried permanently in sediments since then. Another explanation might be different origin and associated different proportion of organic matter stable fraction deposited there due to resuspension and redeposition processes.

Table 2. Linear sediment accumulation rates $\left(\mathrm{cm} \cdot \mathrm{yr} r^{-1}\right)$, mass sediment accumulation rates $\left(g \cdot \mathrm{m}^{-2} \cdot \mathrm{yr} \mathrm{r}^{-1}\right)$, organic carbon accumulation rates $\left(\mathrm{g} \cdot \mathrm{C} \cdot \mathrm{m}^{-2} \cdot \mathrm{yr} \mathrm{r}^{-1}\right)$ and nitrogen accumulation rates $\left(\mathrm{g} \cdot \mathrm{N} \cdot \mathrm{m}^{-2} \cdot \mathrm{yr} \mathrm{r}^{-1}\right)$ in the investigated sediments.

\begin{tabular}{cccccc}
\hline $\begin{array}{c}\text { Sediment } \\
\text { core }\end{array}$ & $\begin{array}{c}\text { Linear sediment } \\
\text { accumulation rate } \\
\left(\mathbf{c m} \cdot \mathbf{y r} \mathbf{r}^{-1}\right)\end{array}$ & $\begin{array}{c}\text { Mass sediment } \\
\text { accumulation rate } \\
\left(\mathbf{g} \cdot \mathbf{m}^{-2} \cdot \mathbf{y r} \mathbf{r}^{-1}\right)\end{array}$ & $\begin{array}{c}\text { Organic carbon } \\
\text { accumulation rate } \\
\left(\mathbf{g} \cdot \mathbf{C} \cdot \mathbf{m}^{-2} \cdot \mathbf{y r} \mathbf{r}^{-1}\right)\end{array}$ & $\begin{array}{c}\text { Accumulation rate } \\
\text { of nitrogen } \\
\left(\mathbf{g} \cdot \mathbf{N} \cdot \mathbf{m}^{-2} \cdot \mathbf{y r} \mathbf{r}^{-1}\right)\end{array}$ & $\begin{array}{c}\text { Ratio of carbon and } \\
\text { nitrogen accumulation } \\
\text { rates }\end{array}$ \\
\hline I & 0.14 & 534 & 34 & 4.4 & 7.7 \\
II & 0.11 & 198 & 23 & 2.3 & 10.0 \\
III & 0.10 & 461 & 43 & 5.0 & 8.6 \\
IV & 0.06 & 320 & 18 & 2.3 & 7.8 \\
V & 0.06 & 410 & 27 & 3.4 & 7.9 \\
VI & 0.16 & 874 & 75 & 8.8 & 8.5 \\
\hline
\end{tabular}


Organic carbon concentration profiles and total nitrogen concentration profiles at all stations except station I exhibit similar shapes. It indicates that nitrogen, carbon and organic matter concentrations changes in the corresponding sediment layers are governed by similar processes. This is clearly seen at sediment core from station III, where the increase of nitrogen and organic carbon concentrations are measured at exactly the same sediment layer $(16-17 \mathrm{~cm})$, indicating untypical origin of sediments constituting the layer.

\section{Accumulation rates of nitrogen}

Total nitrogen concentrations in the investigated sediment samples range from $1.34 \%$ to $0.34 \%$. The highest $\mathrm{N}_{\text {tot }}$ concentrations were measured in sediments from station II. These amounted to $1.34 \%$ in the surface layer

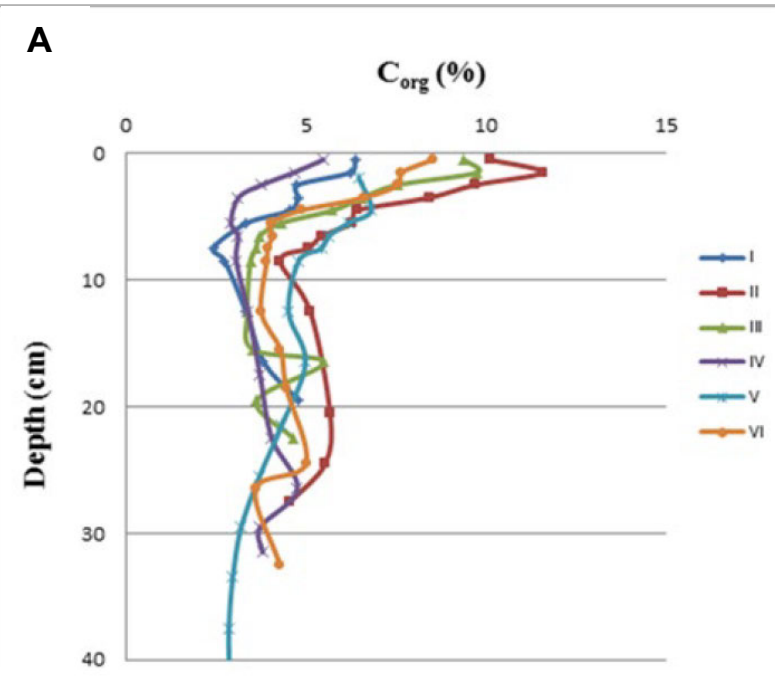

\section{B}

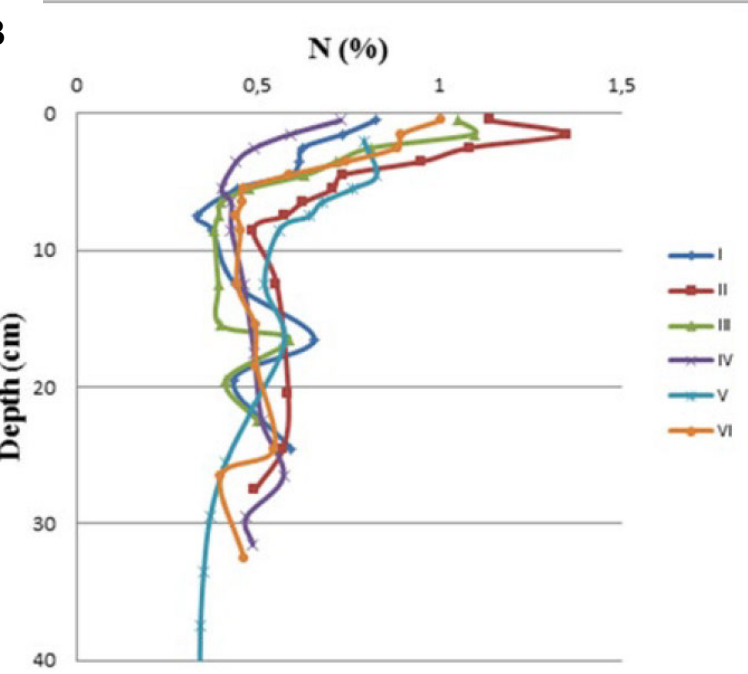

Fig. 3. A - organic carbon concentration against sediment depth, $B$ - total nitrogen concentration against sediment depth. and to $0.48 \%$ in deeper part of the core. The lowest total nitrogen concentrations were measured in the sediment core collected at station IV (0.73-0.42\%) (Fig. 3b.).

Accumulation rates of nitrogen expressed in $\mathrm{g} \cdot \mathrm{N} \cdot \mathrm{m}^{-2} \cdot \mathrm{yr}^{-1}$ was calculated as a product of the mass sediment accumulation rates and the nitrogen concentration measured in sediments. The lowest nitrogen accumulation rate is observed at stations II and IV $\left(2.3 \mathrm{~g} \cdot \mathrm{N} \cdot \mathrm{m}^{-2} \cdot \mathrm{yr}^{-1}\right)$. The highest nitrogen accumulation rate is observed at station VI $\left(8.8 \mathrm{~g} \cdot \mathrm{N} \cdot \mathrm{m}^{-2} \cdot \mathrm{yr}^{-1}\right)$ (Table 2).

As it can be seen, the same trends are observed for nitrogen and organic carbon accumulation rates. The lowest and the highest values of organic carbon accumulation rates occurred in sediments from stations II and VI. However, ratios of $\mathrm{C} / \mathrm{N}$ accumulation in sediments differ considerably, indicating perhaps that not all labile organic matter is actually mineralized in the surface sediments. The matter of $\mathrm{C} / \mathrm{N}$ ratios is discussed, in some detail, below.

\section{Origin of organic matter in the Baltic sediments}

There are several indicators that may be used to assess sedimentary organic matter provenance. The most valuable ones are based on molecular composition of organic substances. Moreover, ratio of $\mathrm{C} / \mathrm{N}$ abundance in the matter is frequently used for the purpose of differentiating land $(\mathrm{C} / \mathrm{N}>12)$ vs. marine $(\mathrm{C} / \mathrm{N}<10)$ origin. Redfield ratio of marine phytoplankton biomass $(\mathrm{C} / \mathrm{N}=7)$ is much smaller than sedimentary organic matter originating from pure marine sources. This indicates that preferential mineralization of organic nitrogen takes place in the course of sedimentation and early diagenesis. The $\mathrm{C} / \mathrm{N}$ ratios encountered in the investigated cores vary in the range from 7.4 to 9.6 (Table 3). This would indicate predominantly marine character of sedimentary organic matter in the

Table 3. $C_{\text {org }} / N_{\text {tot }}$ ratios, $\delta^{13} \mathrm{C}$ and terrestrial organic matter proportion in the surface $(<10 \mathrm{~cm})$ and subsurface $(>20 \mathrm{~cm})$ segments of the investigated cores.

\begin{tabular}{ccccc}
\hline $\begin{array}{c}\text { Sediment } \\
\text { core }\end{array}$ & Layers & C/N ratio & $\begin{array}{c}\mathbf{\delta}^{13} \mathbf{C} \\
\mathbf{( \% 0 )}\end{array}$ & $\begin{array}{c}\text { Terrestrial } \\
\text { organic matter } \\
\text { contribution } \\
(\%)\end{array}$ \\
\hline \multirow{2}{*}{ I } & Surface & $8.6 \pm 0.2$ & $-24.70 \pm 0.08$ & 45.0 \\
& Subsurface & $9.6 \pm 0.5$ & $-24.68 \pm 0.98$ & 44.6 \\
\hline \multirow{2}{*}{ II } & Surface & $8.8 \pm 0.1$ & $-24.56 \pm 0.20$ & 42.7 \\
& Subsurface & $9.5 \pm 0.2$ & $-25.63 \pm 0.10$ & 60.5 \\
\hline \multirow{2}{*}{ III } & Surface & $9.1 \pm 0.2$ & $-24.70 \pm 0.18$ & 45.0 \\
& Subsurface & $9.0 \pm 0.3$ & $-26.36 \pm 0.36$ & 72.7 \\
\multirow{2}{*}{ VV } & Surface & $7.4 \pm 0.3$ & $-24.78 \pm 0.12$ & 46.5 \\
& Subsurface & $8.0 \pm 0.3$ & $-24.63 \pm 0.27$ & 44.2 \\
\hline \multirow{2}{*}{$\mathrm{V}$} & Surface & $8.3 \pm 0.1$ & $-24.61 \pm 0.22$ & 43.5 \\
& Subsurface & $8.8 \pm 0.2$ & $-25.81 \pm 0.08$ & 63.5 \\
\hline \multirow{2}{*}{ VI } & Surface & $8.6 \pm 0.2$ & $-24.45 \pm 0.21$ & 40.8 \\
& Subsurface & $9.0 \pm 0.2$ & $-25.53 \pm 0.06$ & 58.8 \\
\hline
\end{tabular}

${ }^{*}$ standard deviation 
investigated sediments. However, due to the unknown molecular composition of both marine and land components just qualitative assessment as to the organic matter origin can be performed. Moreover, the ratios measured in the sediments may be biased due to the differing mobility of organic carbon and organic nitrogen mineralization products $\left(\mathrm{CO}_{2}\right.$ and $\left.\mathrm{NH}_{3} * \mathrm{H}_{2} \mathrm{O}\right)$. Carbon dioxide largely diffuses out of the sediments to the overlying water, while ammonia is sorbed on sediments particles and thus is retained in sediments (Emeis et al., 2000). Thus the $\mathrm{C} / \mathrm{N}$ ratio can be used for quantitative assessment of organic matter origin, but cautiously (Table 3 ).

It is obvious, however, that $\mathrm{C} / \mathrm{N}$ ratios in the uppermost segments of the cores $(<10 \mathrm{~cm})$ are much lower than these in the subsurface segments $(>20 \mathrm{~cm})$. The border between higher (subsurface) and smaller (surface) ratios is placed at the depths corresponding to deposition period 1930-1950, close to the period when eutrophication in the Baltic has started (Łysiak-Pastuszak, 2000; Voss et al., 2000). For five of the six investigated cores these differences are statistically significant. The average $\mathrm{C} / \mathrm{N}$ ratio in the surface sediments is 8.4. There is one core (IV) with $\mathrm{C} / \mathrm{N}$ ratio (7.4) significantly lower than average, and one core (III) with $\mathrm{C} / \mathrm{N}$ ratio (9.1) - significantly higher. In the latter case the differences seem to indicate increased contribution of terrestrial organic matter, originating possibly from the Bay of Riga, while the former case - accumulation of large quantities of sedimentary material rich with autochthonous organic matter, possibly due to redeposition or sediment slides.

Stable carbon isotopes were also measured in the samples originating from the sediment cores and are presented as $\delta^{13} \mathrm{C}$ in Table 2. The $\delta^{13} \mathrm{C}$ values measured in the sediment samples $\left(\delta^{13} \mathrm{C}_{\mathrm{s}}\right)$ range from $-24.4 \%$ to $26.5 \%$. This is in good agreement with the earlier published data (Voss et al., 2005). The measured values indicate that organic matter in the sediments is a mixture of terrestrial $\left(\delta^{13} \mathrm{C}_{\mathrm{t}}\right.$ equal to $-28 \%$ ) and marine $\left(\delta^{13} \mathrm{C}_{\mathrm{m}}\right.$ equal to $-22 \%$, Boutton, 1991) materials. The $\delta^{13} \mathrm{C}$ values are frequently used for quantitative assessment of terrestrial organic matter $(\mathrm{T} \%)$ contribution in the coastal marine environment (Voss et al., 2005). An end member approach is applied for this purpose, based on the following formula:

$T(\%)=\frac{\delta^{13} c_{s}-\delta^{13} c_{m}}{\delta^{13} c_{t}-\delta^{13} c_{m}} \times 100(\%)$

Results of the so calculated terrestrial contribution to sedimentary organic matter are presented in the Table 3 and Fig. 5. The obtained values, for the surface sediments, are surprisingly uniform, indicating that terrestrial organic matter constitute between $40.8 \%$ and $46.5 \%$ of total organic matter in the surface sediments, independently of the location. Proportion of terrestrial organic matter in subsurface sediments ranges between $44.2 \%$ and $72.7 \%$ (Fig. 4.). Thus it is both much larger and much more varying. This can be attributed to the recent eutrophication of the sea and increased deposition to sediments of autochthonous organic matter (ŁysiakPastuszak, 2000; Voss et al., 2000). This explanation is supported by the high correlation coefficient of the relationship between $\delta^{13} \mathrm{C}$ and $\mathrm{C}$ concentration (Fig. 5). A general agreement between $\delta^{13} \mathrm{C}$ and $\mathrm{C} / \mathrm{N}$ ratios, namely decreasing $\delta^{13} \mathrm{C}$ parallel to increasing values of $\mathrm{C} / \mathrm{N}$, is also evident and most likely caused by mineralization of nitrogen - rich organic matter.

\section{CONCLUSIONS}

The presented study indicates substantial organic carbon and total nitrogen accumulation rates in the sediments of depositional areas of the Baltic Sea. The rates amount to, on average, $35 \mathrm{~g} \cdot \mathrm{C} \cdot \mathrm{m}^{-2} \cdot \mathrm{yr}^{-1}$ and $4 \mathrm{~g} \cdot \mathrm{N} \cdot \mathrm{m}^{-2} \cdot \mathrm{yr}^{-1}$. The values are much higher compared to other shelf seas. This can be attributed to both substantial primary productivity

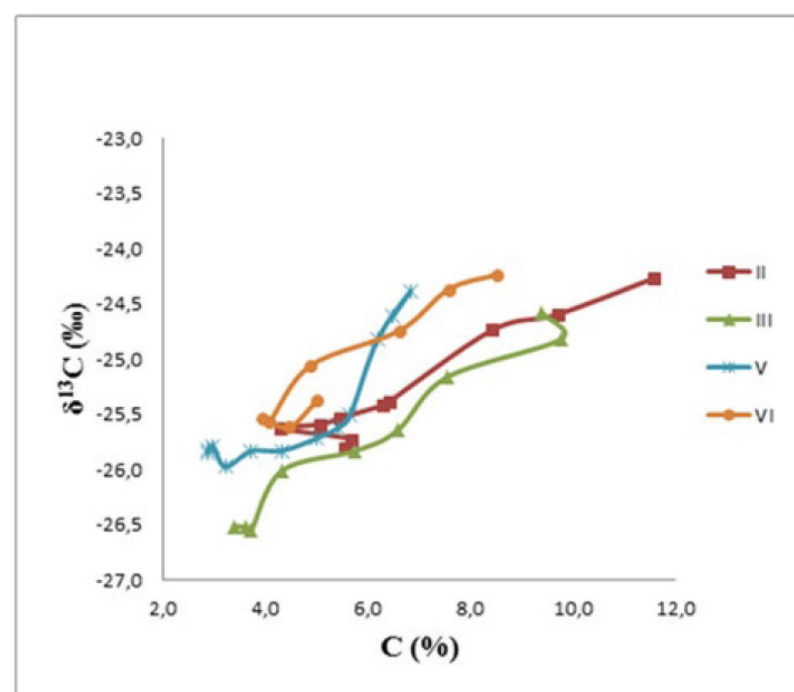

Fig. 4. Relationship between $\delta^{13} \mathrm{C}(\%)$ and $\mathrm{C}(\%)$ concentrations in the investigated sediments.

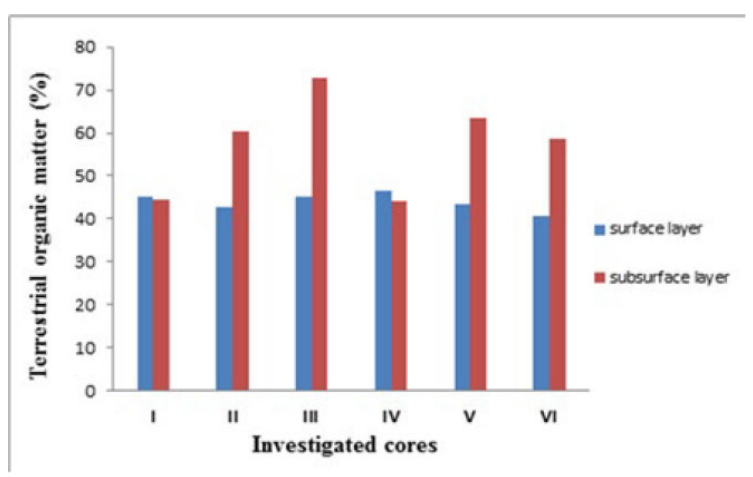

Fig. 5. Terrestrial organic matter contribution in the investigated cores. 
and huge loads of organic matter discharged to the Baltic Sea with river run-off. The latter factor, although decreasing in the importance, still contributes nearly half $(45 \pm 5 \%)$ of sedimentary organic matter in the Gotland Basin and Gdańsk Basin of the Baltic Sea. The obtained results indicate the Baltic Sea sediments as an important sink for organic carbon and total nitrogen. Significant amount of organic carbon accumulated in sediments has an important contribution in carbon cycle of the Baltic Sea.

\section{ACKNOWLEDGEMENTS}

This study was financially supported by the Baltic-C, a Bonus Plus founded project, the BALTEX project founded by the Ministry of Science and Higher Education in Poland, and the NN 306407338 project founded by the Ministry of Science and Higher Education.

\section{REFERENCES}

Abril JM, 2003. Constraints on the use of ${ }^{137} \mathrm{Cs}$ as a time-marker to support CRS and SIT chronologies. Environmental Pollution 129(1): 31-37, DOI 10.1016/j.envpol.2003.10.004.

Borges AV, 2005. Do we have Enough Pieces of the Jigsaw to Integrate $\mathrm{CO}_{2}$ Fluxes in the Coastal Ocean? Estuaries and Coasts 28(1): 327, DOI 10.1007/BF02732750.

Boutton TW, 1991. Stable carbon isotopic ratios of natural materials. II. Atmospheric terrestrial, marine and freshwater environments. In: Coleman DC and Fry B, Eds., Carbon isotope techniques. Academic, San Diego: 173-195

Chen C-TA and Borges AV, 2009. Reconciling opposing views on carbon cycling in the coastal ocean: Continental shelves as sinks and near-shore ecosystems as sources of atmospheric $\mathrm{CO}_{2}$, DeepSea Research II 56(8-10): 578-590, DOI 10.1016/j.dsr2.2009.01.001.

Dzierzbicka-Głowacka L, Kuliński K, Maciejewska A, Jakacki J and Pempkowiak J, 2010. Particulate organic carbon in the southern Baltic Sea: numerical simulations and experimental data. Oceanologia 52(4): 621-648, DOI 10.5697/oc.52-4.621.

Dzierzbicka-Głowacka L, Jakacki J, Janecki M and Nowicki A, 2011. Variability in the distribution of phytoplankton as affected by changes to the main physical parameters in the Baltic Sea. Oceanologia 53(1-TI): 449-470, DOI 10.5697/oc.53-1-TI.449.

Ebbing J, Zachowicz J, Uścinowicz Sz and Laban C, 2002. Normalization as a tool for environmental impact studies: the Gulf of Gdańsk as a case study, Baltica 15: 49-62.

Emeis KC, Struck U, Leipe T, Pollehne F, Kunzendorf H and Christiansen C, 2000. Changes in the $\mathrm{C}, \mathrm{N}, \mathrm{P}$ burial rates in some sediments over the last 150 years - relevance to $P$ regeneration rates and the phosphorus cycle. Marine Geology 167(1-2): 43-59, DOI 10.1016/S0025-3227(00)00015-3.

Emelyanov EM, 1995. Baltic Sea: Geology, Geochemistry, Paleoceanography, Pollution. P.P. Shirshov Institute of Oceanology RAS, Atlantic Branch Baltic Ecological Institute of Hydrosphere Academy of Natural Sciences, RF: $115 \mathrm{pp}$.

Emelyanov EM, 2002. Geology of the Gdańsk Basin - Baltic Sea. Russian Academy of Sciences, Atlantic Branch of P.P. Shirshov Institute of Oceanology.

Flynn WW, 1968. The determination of ${ }^{210} \mathrm{Po}$ in environmental materials, Analytica Chimica Acta 43: 221-227, DOI 10.1016/S00032670(00)89210-7.

Gudelis W and Jemielianowa J, 1982. Geologia Morza Baltyckiego. Wydawnictwa Geologiczne: 412pp.

Hagen E and Feistel R, 2004. Observations of low-frequency current fluctuations in deep water of the Eastern Gotland Basin/Baltic Sea.
Journal of Geophysical Research 109: C03044, DOI: 10.1029/2003JC002017.

HELCOM, 2004. The Fourth Baltic Sea Pollution Load Compilation (PLC-4). Baltic Sea Environment Proceedings 93: 189 pp.

HELCOM, 2006. Development of tools for assessment of eutrophication in the Baltic Sea. Baltic Sea Environmental Proceedings 104: $169 \mathrm{pp}$.

HELCOM, 2007. Climate Change in the Baltic Sea Area. Baltic Sea Environment Proceedings 111:54 pp.

Hille S, Leipe T and Seifert T, 2006. Spatial variability of recent sedimentation rates in the eastern Gotland Basin (Baltic Sea), Oceanologia 48(2): 297-317.

Hongisto M, 2011. Variability of the marine boundary layer parameters over Baltic Sea sub-basins and their impact on nitrogen deposition, Oceanologia 53(1-TI): 391-413, DOI 10.5697/oc.53-1-TI.391.

IPCC, 2007. Climate change 2007, Synthesis Report. A contribution of working groups I, II and III to the Fourth Assessment Report of the Intergovernmental Panel on Climate Change. Cambridge University Press, Cambridge: 73 pp.

Kankaanpaa H, Vallius H, Sandman O and Niemisto L, 1997. Determination of recent sedimentation in the Gulf of Finland using ${ }^{137} \mathrm{Cs}$, Oceanologia Acta 20(6): 823-836 pp.

Kuliński K and Pempkowiak J, 2008. Dissolved organic carbon in the southern Baltic Sea: Quantification of factors affecting its distribution, Estuarine, Coastal and Shelf Science 78(1): 38-44, DOI 10.1016/j.ecss.2007.11.017.

Kuliński $\mathrm{K}$ and Pempkowiak J, 2011. The carbon budget of the Baltic Sea, Biogeosciences 8: 3219-3230, DOI: 10.5194/bg-8-3219-2011.

Kuliński K, She J and Pempkowiak J, 2011. Short and medium term dynamics of the carbon exchange between the Baltic Sea and the North Sea, Continental Shelf Research 31(15): 1611-1619, DOI 10.1016/j.csr.2011.07.001.

Kuliński K and Pempkowiak J, 2012. Carbon cycling in the Baltic Sea, Springer, Heidelberg: $143 \mathrm{pp}$.

Leipe T, Tauber F, Vallius H, Virtasalo J, Uścinowicz Sz, Kowalski N, Hille S, Lindgren S and Myllyvirta T, 2011. Particulate organic carbon (POC) in surface sediments of the Baltic Sea. Geo - Marine Letters 31(3):175-188, DOI 10.1007/s00367-010-0223-x.

Lass HU and Matthäus W, 2008. General Oceanography of the Baltic Sea. Feistel R., Nausch G., Wasund N., State and Evolution of the Baltic Sea, 1952-2005, Wiley\&Sons, Inc., Hoboken, New Jersey: 543

Lima AL, Hubeny JB, Reddy Ch, King JW, Hughen KA and Eglinton $T$, 2004. High-resolution historical records from Pettaquamscutt River basin sediments: $1 .{ }^{210} \mathrm{~Pb}$ and varve chronologies record of ${ }^{137} \mathrm{Cs}$ released by the Czernobyl accident. Geochimica and Cosmochimica Acta 69(7): 1806-1812.

Lysiak-Pastuszak E, 2000. An assessment of nutrient conditions in the southern Baltic Sea between 1994-1998, Oceanologia 42(4): 425448 .

Pempkowiak J, 1985. The input of biochemically labile and resistant organic matter to the Baltic Sea from the Vistula River. Degens E T., Kempe S., Herrera R., Transport of Carbon and Minerals in Major World Rivers, Pt. 3., Mitt. Geol.-Palaont. Inst. Univ. Hamburg, SCOPE/UNEP Sonderband 58: 345-350.

Pempkowiak J, 1991. Enrichment factors of heavy metals in the Southern Baltic surface sediments dated with ${ }^{210} \mathrm{~Pb}$ and ${ }^{137} \mathrm{Cs}$, Environment International 17(5): 421-428, DOI 10.1016/01604120(91)90275-U.

Robins JA, 1978. Geochemical and geophysical applications of radioactive lead. In: Nriagu J. O., (Ed.), The Biogeochemistry of Lead in the environment, Elsevier, Amsterdam: 253-393.

Struck U, Emeis KC, Voss M, Christiansen C and Kunzendorf H, 2000. Records of southern and central Baltic Sea eutrophication in $\delta^{13} \mathrm{C}$ and $\delta^{15} \mathrm{~N}$ of sedimentary organic matter, Marine Geology 164(3-4): 157-171, DOI 10.1016/S0025-3227(99)00135-8.

Szczepańska A, Zaborska A and Pempkowiak J, 2009. Sediment accumulation rates in the Gotland Deep, Baltic Proper obtained by ${ }^{210} \mathrm{~Pb}$ and ${ }^{137} \mathrm{Cs}$ methods, Annual Set the Environment Protection 11(1): 77-85. 
Szczepańska T and Uścinowicz Sz, 1994. Geochemical Atlas of the Southern Baltic; 1:500 000, Polish Geological Institute.

Suplińska M, 2002. Vertical distribution of ${ }^{137} \mathrm{Cs},{ }^{210} \mathrm{~Pb},{ }^{226} \mathrm{Ra}$ and ${ }^{239,240} \mathrm{Pu}$ in bottom sediments from the Southern Baltic Sea in the years 1998-2000, Nukleonika, 47(2): 45-52.

Suplińska M, 2008. Sedimentation rates and dating of bottom sediments in the Southern Baltic Sea region, Nukleonika 53(Supplement 2): S105-S111.

Takahashi T, Sutherland SC, Wanninkhof R, Sweeney C, Feely RA, Chipman DW, Hales B, Friederich G, Chavez F, Sabine Ch, Watson A, Bakker DCE, Schuster U, Metzl N, Yoshikawa-Inoue H,

Ishii M, Midorikawa T, Nojiri Y, Kärtzingerm A, Steinhoffm T, Hoppema M, Olafsson J, Arnarson TS, Tilbrook B, Johannessen T, Olsen A, Bellerby R, Wong CS, Delille B, Bates NR and Baar HJW, 2009. Climatological mean and decadal change in surface ocean pCO2, and net sea-air flux over the global oceans, Deep-Sea Research II 56(8-10): 554-577, DOI 10.1016/j.dsr2.2008.12.009.

Thomas H, Pempkowiak J, Wulff F and Nagl K, 2003. Autotrophy, nitrogen accumulation and nitrogen limitation in the Baltic Sea: A paradox or a buffer for eutrophication? Geophysical Research Letters 30: 2130-2133, DOI 10.1029/2003GL017937.

Thomas H, Pempkowiak J, Wulff F and Nagel K, 2010. The Baltic Sea, Carbon and Nutrient Fluxes in Continental Margins, Springer: 234-245.
Voipio A, 1981. The Baltic Sea, Elsevier Scientific Publishing Company.

Voss M, Larsen B, Leivuori M, Vallius H, 2000. Stable isotope signals of eutrophication in Baltic Sea sediments, Journal of Marine Systems 25(3-4): 287-298, DOI 10.1016/S0924-7963(00)00022-1.

Voss M, Emeis KC and Hille S, 2005. Nitrogen cycle of the Baltic Sea from an isotopic perspective, Global Biogeochemical Cycles 19: GB3001, DOI 10.1029/2004GB002338.

Walter S, Breitenbach U, Barge HW, Nausch G and Wallace DWR, 2006. Distribution of $\mathrm{N}_{2} \mathrm{O}$ in the Baltic Sea during transition from anoxic to oxic conditions, Biogeosciences 3: 557-570, DOI $10.5194 /$ bg-3-557-2006.

Wasmund N and Uhlig S, 2003. Phytoplankton trends in the Baltic Sea. Journal of Marine Systems 60(2): 177-186, DOI 10.1016/S10543139(02)00280-1.

Widrowski H and Pempkowiak J, 1986. The history of surface sediments in the Southern Baltic, Proc. 15th Conf. Baltic Oceanogr. Mar. Pollut. Lab., Copenhagen: 656-671.

Zaborska A, Carrol J, Papucci C and Pempkowiak J, 2007. Intercomparison of alpha and gamma spectrometry techniques used in $\mathrm{Pb}-210$ geochronology, Journal of Environmental Radioctivity 93(1): 3850, DOI 10.1016/j.jenvrad.2006.11.007.

Zaborska A, Carrol J, Papucci C, Torricelli L, Carrol M, WalkuszMiotk J and Pempkowiak J, 2008. Recent sediment accumulation rates for the Western margin of the Barents Sea, Deep-Sea Research II 55(20-21): 2352-2360, DOI 10.1016/j.dsr2.2008.05.026. 